\title{
Normalization of the levels of inflammatory molecules in Mycobacterium smegmatis-infected U937 cells by fibrate pretreatment
}

\author{
Sung-Jo Kim ${ }^{1}$, Minho Hong ${ }^{1}$, Ki Duk Song ${ }^{2}$, Hak-Kyo Lee ${ }^{2}$, Sungweon Ryoo ${ }^{3}$ and Tae-Hwe Heo ${ }^{4,5^{*}}$
}

\begin{abstract}
Background: Tuberculosis (TB) is a respiratory tract disease caused by Mycobacterium tuberculosis infection. $M$. tuberculosis exploits immune privilege to grow and divide in pleural macrophages. Fibrates are associated with the immune response and control lipid metabolism through glycolysis with $\beta$-oxidation of fatty acids.

Results: In this study, we investigated the effect of fibrate pretreatment on the immune response during $M$. smegmatis infection in U937 cells, a human leukemic monocyte lymphoma cell line. The protein expression of tumor necrosis factor a (TNF-a), an inflammatory marker, and myeloid differentiation primary response gene 88 (MyD88), a toll like receptor adaptor molecule, in the infected group increased at 1 and $6 \mathrm{~h}$ after $\mathrm{M}$. smegmatis infection of U937 cells. Acetyl coenzyme A acetyl transferase-1 (ACAT-1), peroxisome proliferator-activated receptor-a (PPAR-a), TNF-a, and MyD88 decreased in U937 cells treated with fibrates at 12 and $24 \mathrm{~h}$ after treatment. More than a $24 \mathrm{~h}$ pretreatment with fibrate resulted in similar expression levels of ACAT-1 and PPAR-a between infected vehicle control and infected groups which were pretreated with fibrate for $24 \mathrm{~h}$. However, upon exposure to M. smegmatis, the cellular expression of the TNF- $a$ and MyD88 in the infected groups pretreated with fibrate for $24 \mathrm{~h}$ decreased significantly compared to that in the infected vehicle group.
\end{abstract}

Conclusion: These results suggest that fibrate pretreatment normalized the levels of inflammatory molecules in Mycobacterium smegmatis-infected U937 cells. Further studies are needed to confirm the findings on pathophysiology and immune defense mechanism of U937 by fibrates during $M$. tuberculosis infection.

Keywords: Fibrate, MyD88, TNF-a, Tuberculosis

\section{Background}

Mycobacterium tuberculosis causes tuberculosis (TB) infection, a disease which kills two million people every year [1-3]. Phagocytosis of M. tuberculosis by alveolar macrophages results in the accumulation of oxidized low-density lipoproteins which provides immune privilege to the pathogen. M. tuberculosis exists inside a granuloma, a hallmark of TB. However, the underlying mechanism of TB pathogenesis is not fully understood [4-6]. Because M. tuberculosis is highly infectious and

\footnotetext{
* Correspondence: thhur92@catholic.ac.kr

${ }^{4}$ Laboratory of Immunology, Integrated Research Institute of Pharmaceutical Sciences, College of Pharmacy, The Catholic University of Korea, Bucheon 420-743, Republic of Korea

${ }^{5}$ NP512, Hall of Cardinal Jin-Suk Cheong, The Catholic University of Korea, 43 Jibong-ro, Wonmi-gu, Bucheon-si, Gyeonggi-do 420-743, Republic of Korea Full list of author information is available at the end of the article
}

must be handled in a biosafety level-3 or above facility, research on the mechanism of TB infection has generally been performed using alternative mycobacterium species such as M. smegmatis, M. bovis, Bacillus calmette-guerin (BCG) or M. marinum [7-10]. Detection of mannose-6phosphate isomerase class I (ManA) and methionine amino peptidase (MetAP) using polymerase chain reaction (PCR) has been performed to diagnose mycobacteria infection in macrophages [4,11-13]. Furthermore, ManA [14] and MetAP [12] from M. tuberculosis have been regarded as promising antituberculosis targets. Fibrates affect lipid and lipoprotein metabolism through activating transcription factors including peroxisome proliferator-activated receptor- $\alpha$ (PPAR- $\alpha$ ) [15]. About 80 fibrate substances are synthesized from dehydrocholic acid, phenylethyl acetic acid, and other acetic acids and studies have shown the effects of hypocholesterolemia in 
both humans and rats [16-19]. Several fibrates have been developed, including bezafibrate, fenofibrate, and gemfibrozil. Fenofibrate and gemfibrozil have been used in North America and bezafibrate and ciprofibrate in Europe. The direct effect of fibrates on TB infection have not been studied well. Among fibrates, it was reported that gemfibrozil, a commonly prescribed hypolipidemic drug, blocked TB growth by inhibiting enoyl reductase [20] and bezafibrate differentiates human myeloid leukemia cells [21].

PPAR- $\alpha$ belongs to the large PPAR nuclear receptor superfamily and forms a heterodimer with the 9-cisretinoic acid receptor (RXR) to bind to the peroxisome proliferator response element complex, which is a transcriptional regulatory element controlling lipid and carbohydrate metabolism with hypolipidemic effects [22-25]. In addition, PPAR- $\alpha$ is involved in endothelial dysfunction, myocardial ischemic injury, and immuneinflammatory responses in cells [26]. Cholesterol levels of host cells have an effect on TB infection, as a high level of cholesterol in the diet contributes to increase in TB infection rate $[16,18,19]$. In addition, TB is known to aggress upon host cells via cholesterol-rich membrane microdomains $[2,3,27]$. Despite the possible mutual link between TB and PPAR- $\alpha$ via lipid metabolism, the direct involvement of PPAR- $\alpha$ in TB pathogenesis is still obscure.

In the case of bacterial infection including $\mathrm{TB}$, several immune response factors, such as nuclear factor kappa beta $(\mathrm{NF}-\mathrm{kB})$ and tumor necrosis factor- $\alpha$ (TNF- $\alpha)$ in human monocytes, play important roles in innate immunity and function, leading to migration of NF- $\mathrm{kB}$ into the nucleus by immune signal transduction via TLR2 $[28,29]$. Especially, TNF- $\alpha$ is involved at multiple steps in immune response to $M$. tuberculosis [30]. In addition, myeloid differentiation primary response gene 88 (MyD88) is important for triggering macrophage effector mechanisms against $M$ tuberculosis [31]. PPAR- $\alpha$ activator, gemfibrozil, has shown the inhibitory effect of TNF- $\alpha$ partly by antagonizing NF- $\mathrm{KB}$ in neonatal rat cardiac myocytes [32].
Acetyl coenzyme A acetyl transferase-1 (ACAT-1) is a mitochondrial enzyme that participates in the degradation and formation of ketone bodies, and synthesis of acetoacetyl-CoA using two acetyl-CoAs $[5,6,33,34]$. Acetoacetyl-CoA is converted to cholesterol in the early cholesterol biosynthetic pathway [8-10,35,36]. Despite the possible mutual link between TB and ACAT-1 via lipid metabolism, the direct involvement of ACAT-1 in TB pathogenesis is still obscure.

In this study, we intended to investigate the impact of fibrates treatment on M. smegmatis infected cells, and observed that pretreatment of differentiated U937 cells with fibrate affects the expression of PPAR- $\alpha$, which is a target receptor of fibrates, myeloid differentiation primary response gene 88 (MyD88), which participates in the immune response, and acetyl coenzyme A acetyl transferase-1 (ACAT-1), which participates in TNF- $\alpha$ activation and early cholesterol pathway, consequently alleviated infection by $M$. smegmatis in macrophages.

\section{Results}

Identification of M. smegmatis infection

The U937 cells differentiated by PMA were exposed to $M$. smegmatis to identify the infection. After lysis of differentiated U937 cells, the collected genomic DNA was used with a specific primer designed for mannose-6-phosphate isomerase class I (ManA) and methionine amino peptidase (MetAP), which are both specifically expressed in $M$. smegmatis. ManA and MetAP bands were observed, and, thus, M. smegmatis infection in the U937 cells was confirmed (Figure 1).

\section{Differential expression of ACAT-1, PPARa, TNF- $a$, and MyD88 in U937cells infected with M. smegmatis}

Western blotting was performed to identify the effect of $M$. smegmatis infection in U937 cells by examining the expression of ACAT-1, PPAR $\alpha$, TNF- $\alpha$, and MyD88 (Figure 2). The expression level of ACAT- 1 in the infected group was significantly different at $12 \mathrm{~h}$ after infection compared to

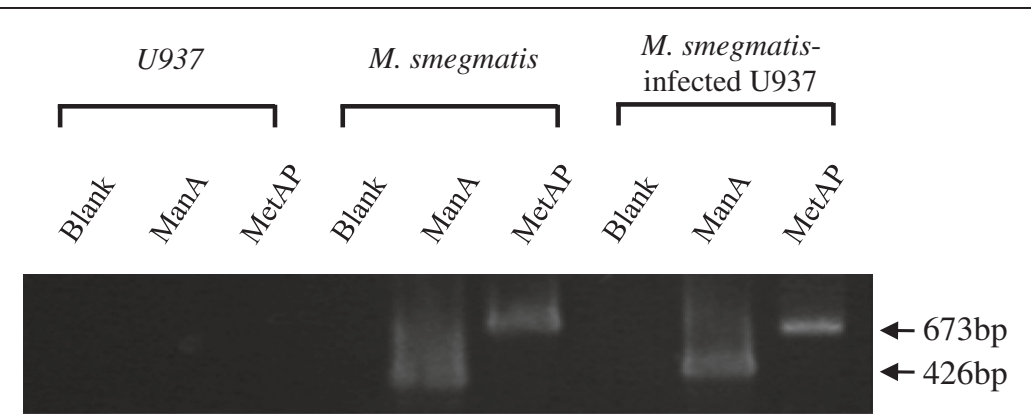

Figure 1 Mycobacterium smegmatis infection analysis performed by polymerase chain reaction. mannose-6-phosphate isomerase class I (ManA) and methionine amino peptidase (MetAP) bands were detected using specific primers with bacterial genomic DNA or that from M. smegmatis-infected U937 cells. B. 

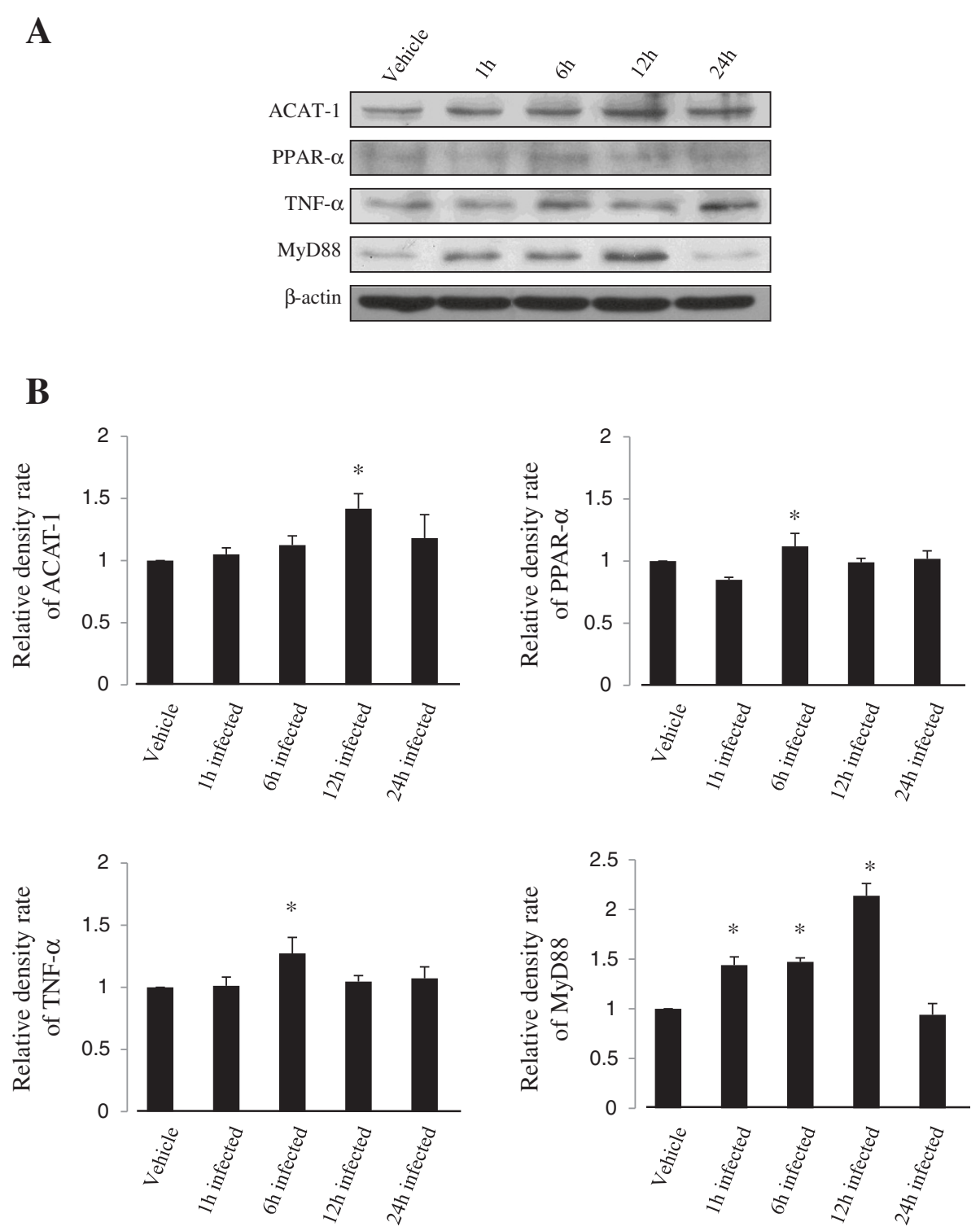

Figure 2 Fibrate pretreatment affects acetyl coenzyme A acetyl transferase-1 (ACAT-1), peroxisome proliferator-activated receptor- $a$ (PPAR-a), tumor necrosis factor-a (TNF-a), and myeloid differentiation primary response gene 88 (MyD88) expression patterns in U937 cells. (A) The expression patterns of various factors at $12 \mathrm{~h}$ or $24 \mathrm{~h}$ are shown after treatment with fibrates. The expression patterns associated with all factors decreased after $12 \mathrm{~h}$ and $24 \mathrm{~h}$ compared with those in the untreated control. $\beta$-actin was used as the loading control. (B) Each protein density of fibrate-treated cells were normalized to that of untreated vehicle cells. Each result represents the mean \pm SD of three experiments. Significance was calculated as * $p$ value $<0.05$ compared to the control by Student's unpaired $t$-test. Beza, bezafibrate; Feno, fenofibrate; Gem, gemfibrozil.

that of the non-infected vehicle control (ACAT-1, $1 \mathrm{~h}$ infection; $1.05 \pm 0.05, p>0.01,6$ h infection; $1.12 \pm 0.07$, $p>0.01,12 \mathrm{~h}$ infection; $1.42 \pm 0.05 \mathrm{p}<0.05,24 \mathrm{~h}$ infection; $1.18 \pm 0.19, p>0.05$ ), whereas PPAR- $\alpha$ expression decreased slightly at $1 \mathrm{~h}$ after $M$. smegmatis infection (PPAR- $\alpha, 1 \mathrm{~h}$ infection; $0.85 \pm 0.02, p<0.05,6 \mathrm{~h}$ infection; $1.12 \pm 0.10, p>0.05,12 \mathrm{~h}$ infection; $0.99 \pm 0.03, p>0.05$, $24 \mathrm{~h}$ infection; $1.02 \pm 0.06, p>0.05)$ and increased at $6 \mathrm{~h}$ after M. smegmatis infection. TNF- $\alpha$ expression increased by about $30 \%$ at $6 \mathrm{~h}$ and then decreased to normal expression levels at $24 \mathrm{~h}$. (TNF- $\alpha, 1 \mathrm{~h}$ infection; $1.01 \pm 0.07$, $p>0.05,6 \mathrm{~h}$ infection; $1.27 \pm 0.13, p<0.05,12 \mathrm{~h}$ infection; $1.05 \pm 0.05, p>0.05,24 \mathrm{~h}$ infection; $1.07 \pm 0.09 \mathrm{p}>0.05$ ) MyD88 expression increased significantly at 1,6 , and $12 \mathrm{~h}$ after $M$. smegmatis infection. (MyD88, $1 \mathrm{~h}$ infection; 1.44 $\pm 0.08, p>0.05,6$ h infection; $1.47 \pm 0.04, p<0.01$, 
$12 \mathrm{~h}$ infection; $2.14 \pm 0.12, p<0.01,24 \mathrm{~h}$ infection; $1.18 \pm 0.19, p>0.05)$.

\section{Expression of ACAT-1, PPAR- $a$, TNF- $a$, and MyD88 after} U937 cell pretreatment with fibrates

Bezafibrate, fenofibrate, and gemfibrozil were selected among the commonly available fibrates to study their effects on differentiated U937 cells. Western blotting was used to identify ACAT-1, which participates in early cholesterol synthesis, PPAR- $\alpha$, which is a fibrate receptor, TNF- $\alpha$, which is a inflammatory cytokine, and MyD88, which is a promoter of signal transduction for $\mathrm{TB}$ and binds to the Toll like receptor 2 (TLR2) membrane protein (Figure 3). ACAT-1, PPAR- $\alpha$, and TNF- $\alpha$ expression

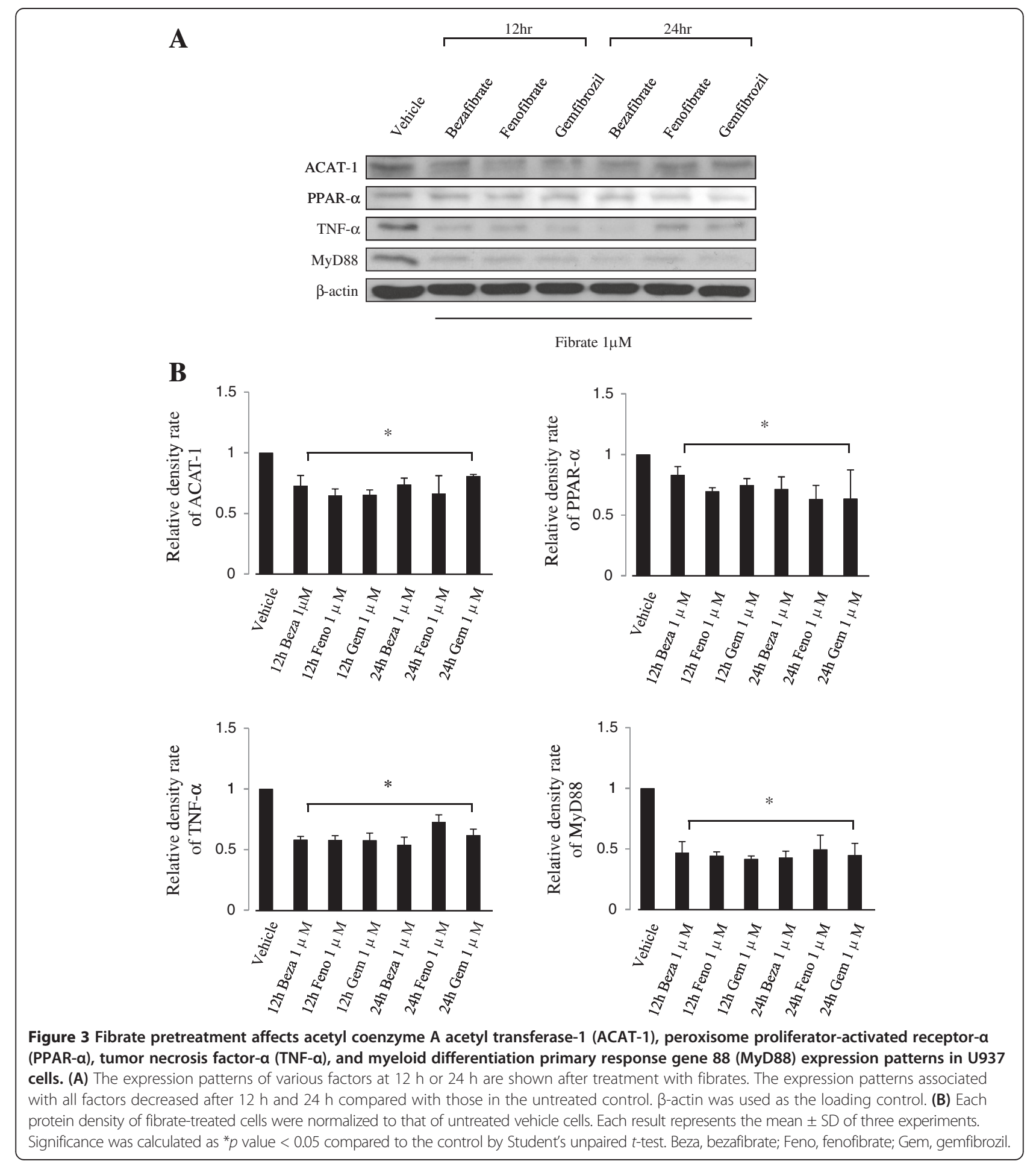


levels decreased about 15-35\% compared with that in the vehicle control following treatment with bezafibrate, fenofibrate, or gemfibrozil. MyD88 in U937 cells treated with fibrates decreased by about $50 \%$ compared with that in the control group, and the decrease was generally maintained for $24 \mathrm{~h}$ or more.

\section{The effect of fibrate pretreatment on ACAT-1, PPARa, TNF- $\alpha$, and MyD88 protein expression in U937 cells infected by $M$. smegmatis}

ACAT-1 protein expression in the infected group increased slightly at $6 \mathrm{~h}$ after infection compared to that in the non-infected vehicle control, but the difference was not significant. PPAR- $\alpha$ protein expression was also not significantly different between the infected and vehicle control groups and the fibrate pretreated group.

However, TNF- $\alpha$ protein expression decreased about $50 \%$ in the bezafibrate, $55 \%$ in the fenofibrate, and $25 \%$ in the gemfibrozil treated groups compared with that in the non-infected vehicle control group at $1 \mathrm{~h}$ after infection. At $6 \mathrm{~h}$, the TNF- $\alpha$ had decreased about 35\% in the bezafibrate, $40 \%$ in the fenofibrate, and $25 \%$ in the gemfibrozil treated cells ( $1 \mathrm{~h}$ infection: $24 \mathrm{~h}$ bezafibrate treatment; $0.49 \pm 0.13, p<0.01,24 \mathrm{~h}$ fenofibrate treatment; $0.44 \pm 0.12, p<0.01,24 \mathrm{~h}$ gemfibrozil treatment; $0.75 \pm$ $0.13, p<0.05,6 \mathrm{~h}$ infection: infected control; $1.26 \pm 0.12$, $p<0.05,24$ h bezafibrate treatment; $0.65 \pm 0.17, p<0.05$, $24 \mathrm{~h}$ fenofibrate treatment; $0.58 \pm 0.15, p<0.01,24 \mathrm{~h}$ gemfibrozil treatment; $0.74 \pm 0.13, p<0.05)$.

MyD88 increased in infected cells (Figure 4, panels a and $b$, lane 2) compared with that in the non-infected vehicle control group, whereas the protein level was not different in fenofibrate and gemfibrozil treated cells compared to that in the non-infected vehicle control at 1 and $6 \mathrm{~h}$, respectively. MyD88 expression in the bezafibrate treated group was not significantly different compared to that in the vehicle control group at $1 \mathrm{~h}$; however, it decreased to the non-infected vehicle control level at $6 \mathrm{~h}$ ( $1 \mathrm{~h}$ infection: infected vehicle control; $2.17 \pm 0.20, p<0.01$, $24 \mathrm{~h}$ bezafibrate treatment; $2.00 \pm 0.04, p<0.01,6 \mathrm{hr}$ infection: infected vehicle control; $2.52 \pm 0.19, \quad p<0.01$ ) (Figure 4).

\section{Discussion}

Tuberculosis is an infectious disease caused by M. tuberculosis that grows and divides in pleural macrophages. Fibrates are associated with the immune response and control of the intracellular lipid metabolism. In this study, we investigated the effect of fibrate pretreatment on the immune response during $M$. smegmatis infection in the U937 human leukemic monocyte lymphoma cell line. Our results suggest that fibrate pretreatment reduced the inflammatory stresses in M. smegmatis-infected U937 cells through a PPAR- $\alpha$ independent pathway.
ManA belongs to phosphomannose isomerase and is encoded by the ManA gene, which interconverts fructose6-phosphate and mannose-6-phosphate [4]. Methionine amino peptidase is encoded by the MetAP gene and deletes the $\mathrm{N}$-terminal methionine from polypeptides during protein synthesis in eukaryotes and prokaryotes [7]. Genes of both enzymes were found in M. smegmatis $[4,11]$. In this study, M. smegmatis was collected from U937 cells exposed to M. smegmatis to confirm infection. The genomic DNA was then used in a PCR reaction with ManA and MetAP specific primers. Bands appeared at the same size as the control group; thus, confirming infection by $M$. smegmatis (Figure 1).

The effect of $M$. smegmatis infection on target protein expression in U937 cells was identified by Western blot. The expression of ACAT-1, TNF- $\alpha$, PPAR- $\alpha$, and MyD88 increased (Figure 2). Especially, the expression of MyD88, which binds to TLR2, a receptor of Mycobacterium spp. [29], markedly increased in M. smegmatis-infected U937 cells (Figure 2). Inflammatory responses to M. smegmatis infection could be predicted in U937 cells due to the elevated expression of TNF- $\alpha$ and MyD88.

Western blotting was performed using ACAT-1 antibodies on fibrate-treated U937 cells to examine the effect of bezafibrate, fenofibrate, and gemfibrozil on U937 cells (Figure 3). ACAT-1 participates in the degradation and formation of ketone bodies and cholesterol biosynthetic pathway $[35,36]$. ACAT-1 protein expression was suppressed in fibrate pretreated U937 cells, which may represent increased lipid $\beta$-oxidation, and both cholesterol and ketone body synthesis were inhibited (Figure 3). However the ACAT-1 expression pattern did not change following $M$. smegmatis infection (Figure 4). Our results indicate that the M. smegmatis infection mechanism has no relationship with the cholesterol and ketone body synthetic pathway.

Fibrates are known to inhibit lipid synthesis and lipid metabolism via activation of PPAR- $\alpha[15,37,38]$ and effect of lipid metabolism during TB infection has been reported in numerous studies $[16,18,19,27]$. Phagocytosis control, enabled by control of other lipid metabolism, can inhibit infection. The effects of fibrates, which are PPAR- $\alpha$ agonists, on PPAR- $\alpha$ expression in M. smegmatis-infected U937 cells was investigated. Their expression patterns were not so different under fibrate pretreatment; thus, the effect of PPAR- $\alpha$ signaling on the infection mechanism was unclear (Figure 4). Because it was reported and hypothesized that gemfibrozil blocked TB by inhibiting enoyl reductase [20] or by regulating cholesterol metabolism via ROR $\gamma$ inhibition in macrophages [39], other targets or mechanism of fibrates except for PPAR- $\alpha$ could be deduced.

The cells were pretreated with fibrates for $24 \mathrm{~h}$ prior to exposure to M. smegmatis for 1 or 6 hours to examine 


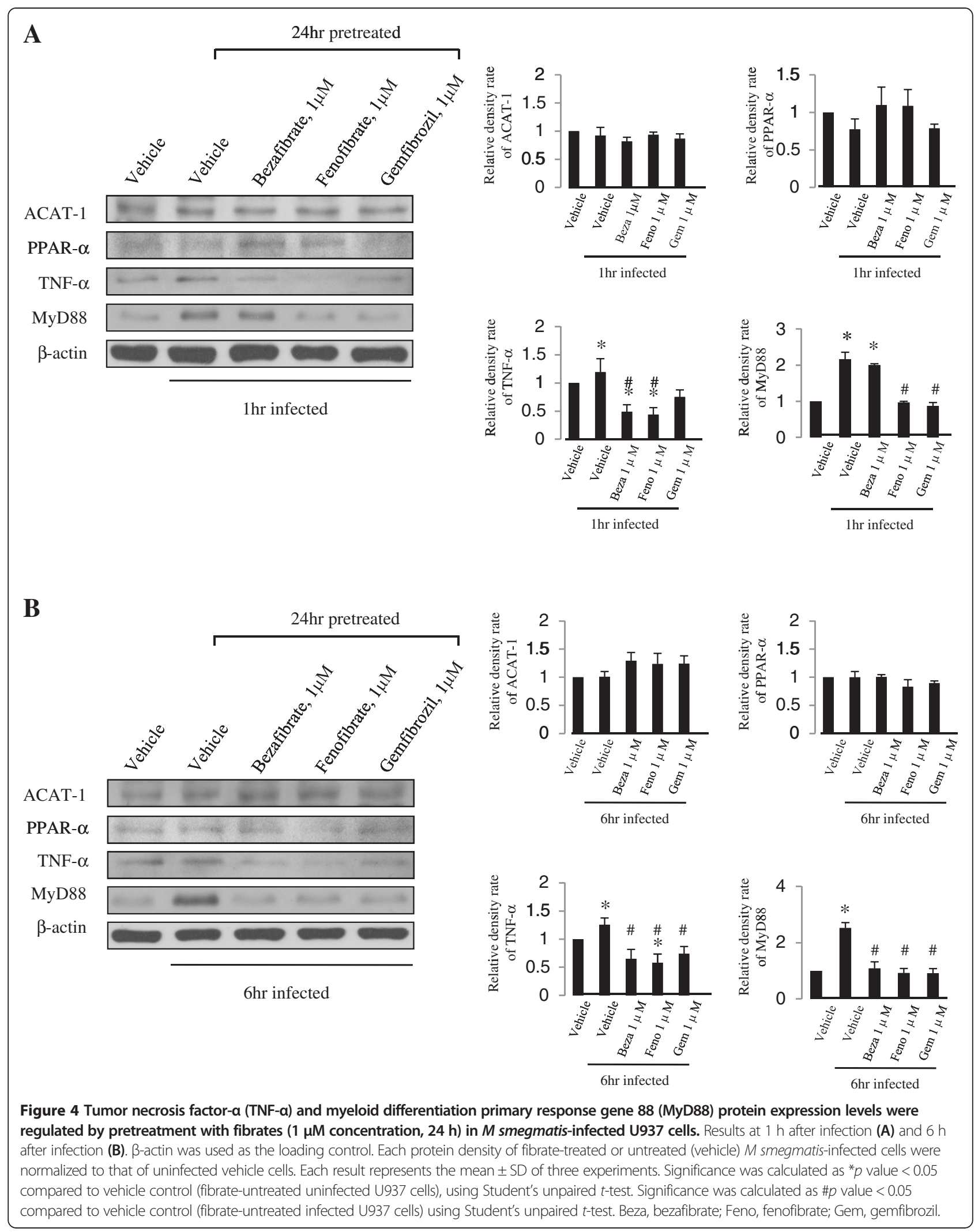


the effect of fibrate pretreatment on M. smegmatis infection in U937 cells. Western blotting was used to observe changes in the expression of inflammatory protein, MyD88 and TNF- $\alpha$. Fibrate-treatment resulted in downregulation of MyD88 and TNF- $\alpha$ expression at 1 and $6 \mathrm{~h}$ after infection in U937 cells (Figure 4). MyD88 is a messenger of TLR signaling during a TB infection $[17,29]$ and TNF- $\alpha$ is important in the macrophage infection mechanism via TB phagocytosis [40-42]. It was reported that fibrates could target membrane isoprenoid quinones and could show toxicity in M. tuberculosis [43], possibly resulting in the reduction of the burden of infection and inflammation. Since TNF- $\alpha$ and MyD88 have been regarded as a critical component of the inflammatory immune response to $M$. tuberculosis, the normalization of their expression possibly means the amelioration of pathologic condition of fibrate pretreated differentiated macrophages or the decrease in the infection rate.

\section{Conclusion}

Our data suggest that fibrate pretreatment normalized the levels of inflammatory molecules in Mycobacterium smegmatis-infected U937 cells. The possible effect of fibrate treatment on $M$. smegmatis in macrophages was suggested here by examination of protein expression of ACAT-1, PPAR- $\alpha$, TNF- $\alpha$, and MyD88. New approaches using fibrates to evaluate TB infection could function to explain the mechanism of host immune response and the infection inhibition. Further studies are needed to establish the mechanism of action of fibrates in inhibiting Mycobacterium spp. infection.

\section{Methods}

\section{Cell culture and differentiation}

Human leukemic lymphoma U937 cells were cultured on $100 \mathrm{~mm}$ cell culture plates in RPMI 1640 medium (Caisson Labs, Logan, UT, USA) with 10\% fetal bovine serum (Thermo Scientific, Waltham, MA, USA), 1\% penicillin-streptomycin (Invitrogen, Carlsbad, CA, USA) and $1 \%$ sodium pyruvate (Welgene, Seoul, Korea) at $37^{\circ} \mathrm{C}$ in an incubator (Thermo Scientific) containing 95\% air and $5 \% \mathrm{CO}_{2}$. The cells were differentiated by treatment with phorbol myristate acetate (PMA, $10 \mu \mathrm{g} / \mathrm{ml}$, Sigma, St Louis, MO) for $72 \mathrm{~h}$ [1].

\section{Bacteria}

Mycobacterium smegmatis $\left(\mathrm{mc}^{2} 155\right)$, stored at $-70^{\circ} \mathrm{C}$, was thawed and then resuspended in RPMI 1640 medium for the infection test.

\section{M. smegmatis infection assayed by PCR}

Differentiated U937 cells were exposed to M. smegmatis for $1 \mathrm{~h}$ (multiplicity of infection, MOI, 5:1 mycobacteria to cell ratio). The U937 cells were removed from the medium and washed with PBS three times, and $\mathrm{dH}_{2} \mathrm{O}$ was added to lyse the U937 cells through osmosis. The supernatant was transferred to new tubes and centrifuged. The resulting bacteria pellet was resuspended in Tris-EDTA buffer. The bacteria were boiled at $100^{\circ} \mathrm{C}$ for $3 \mathrm{~min}$, and then PCR analysis was performed on their genomic DNA using the following sense and antisense primers: ManA, forward primer 5'-TCGACGGCGCGATCAACT AC-3' (527-546), reverse primer 5'ATCTCGTGTCCG AGCTGCTC-3' (931-950); MetAP, forward primer 5'CACGACCGCTGAACGAACTC-3' (8-27), reverse primer 5'-GACGCTGGAGCAGTTCGTTG-3' (640-659). The thermocycling protocol used for amplification of ManA and MetAP included 35 cycles of $95^{\circ} \mathrm{C}$ for $60 \mathrm{~s}, 58.5^{\circ} \mathrm{C}$ for $60 \mathrm{~s}$, and $72^{\circ} \mathrm{C}$ for $1.5 \mathrm{~min}$, followed by $10 \mathrm{~min}$ of final extension at $72^{\circ} \mathrm{C}$. The PCR products were separated using electrophoresis on a $1.2 \%$ agarose gel and visualized by ethidium bromide staining.

\section{Western blotting}

Differentiated U937 cells $\left(2.5 \times 10^{6}\right)$ were cultured on $100 \mathrm{~mm}$ plates in medium and then mixed with either dimethyl sulfoxide (0.001\% DMSO), as the vehicle control, or with $1 \mu \mathrm{M}$ of each fibrate (bezafibrate, fenofibrate, and gemfibrozil) for $24 \mathrm{~h}$ at $37^{\circ} \mathrm{C}$ in an incubator (Thermo Scientific) containing 95\% air and 5\% $\mathrm{CO}_{2}$. After $24 \mathrm{~h}$, the treated cells were exposed to M. smegmatis for $1 \mathrm{~h}$ or $6 \mathrm{~h}$ (MOI, 5:1). After washing with PBS, the proteins were extracted using RIPA buffer (Novagen, Madison, WI, USA). A protease-inhibitor cocktail (Sigma, St Louis, MO, USA Catalog Number P2714) was added at each step to extract the proteins. From each sample, 15$40 \mu \mathrm{g}$ of protein was extracted and electrophoresed on a sodium dodecyl sulfate polyacrylamide gel (Bio-Rad, Hercules, CA, USA). The proteins were then transferred to a polyvinylidene fluoride membrane (Bio-Rad) for Western blot analysis. The protein-containing membrane was blocked using 5\% skim milk (Bio-Rad) and then incubated with primary anti-ACAT-1 (Santa Cruz Biotechnology, Santa Cruz, CA, USA), anti-PPAR $\alpha$ (Santa Cruz Biotechnology), anti-TNF- $\alpha$ (Santa Cruz Biotechnology), antiMyD88 (Santa Cruz Biotechnology) or anti- $\beta$-actin (Sigma) antibodies. Subsequently, anti-mouse (Santa Cruz Biotechnology), anti-rabbit (Santa Cruz Biotechnology) or anti-goat (Santa Cruz Biotechnology) secondary antibodies was incubated with the membrane, and the protein band was visualized using Super-Signal West Pico Luminal/Enhancer solution (Thermo Scientific). All images were enhanced using Photoshop (Adobe Systems, San Jose, CA, USA).

\section{Statistical analysis}

Experiments were performed in triplicate. Statistical significance was evaluated by Student's t-test using the TINA 2.0 
densitometric analytical system (Raytest, Straubenhardt, Germany). P values $<0.05$ were considered significant.

\begin{abstract}
Abbreviations
ACAT-1: Acetyl transferase-1; BCG: Bacillus calmette-guerin; DMSO: Dimethyl sulfoxide; ManA: Mannose-6-phosphate isomerase class I; MetAP: Methionine amino peptidase; MyD88: Myeloid differentiation primary response gene 88; PCR: Polymerase chain reaction; PMA: Phorbol myristate acetate; PPAR-a: Peroxisome proliferator-activated receptor-a; RXR: Retinoic acid receptor; TB: Tuberculosis; TLR: Toll like receptor; TNF-a: Tumor necrosis factor $a$.
\end{abstract}

\section{Competing interests}

The authors declare that they have no competing interests.

\section{Authors' contributions}

SJK and $\mathrm{MH}$ carried out the experiments and drafted the manuscript. KDS, $H K L$, and SR participated in the design of the study and performed the statistical analysis. THH carried out the design of the study and drafted and revised the manuscript. All authors read and approved the final manuscript

\section{Authors' information}

Sung-Jo Kim and Minho Hong are co-first authors.

\section{Acknowledgements}

This study was supported by the Research Fund 2011 of The Catholic University of Korea. This research was supported by a grant from Next generation of the BioGreen 21 project (PJ008196) from Rural Development Administration, Republic of Korea.

\section{Author details}

'Department of Biotechnology, Hoseo University, 165, Baebang, Asan, Chungnam 336-795, Republic of Korea. ${ }^{2}$ The Animal Genomics and Breeding Center, Han-Kyong National University, Anseong 456-749, Republic of Korea. ${ }^{3}$ Korean Institute of Tuberculosis, Mansu-ri 482, Gangoe-myeon, Cheongwon-gun, Chungcheongbuk-do 363-954, Republic of Korea. ${ }^{4}$ Laboratory of Immunology, Integrated Research Institute of Pharmaceutical Sciences, College of Pharmacy, The Catholic University of Korea, Bucheon 420-743, Republic of Korea. ${ }^{5}$ NP512, Hall of Cardinal Jin-Suk Cheong, The Catholic University of Korea, 43 Jibong-ro, Wonmi-gu, Bucheon-si, Gyeonggi-do 420-743, Republic of Korea.

Received: 21 June 2014 Accepted: 5 September 2014

Published: 15 September 2014

\section{References}

1. Kitamura H, Nakagawa T, Takayama M, Kimura Y, Hijikata A, Hijika A, Ohara O: Post-transcriptional effects of phorbol 12-myristate 13-acetate on transcriptome of U937 cells. FEBS Lett 2004, 578:180-184.

2. North RJ, Jung Y-J: Immunity to tuberculosis. Annu Rev Immunol 2004, 22:599-623.

3. Raviglione MC, Dye C, Schmidt S, Kochi A: Assessment of worldwide tuberculosis control: WHO Global Surveillance and Monitoring Project. The Lancet 1997, 350:624-629.

4. Patterson JH, Waller RF, Jeevarajah D, Billman-Jacobe H, McConville MJ: Mannose metabolism is required for mycobacterial growth. Biochem J 2003, 372:77-86.

5. Hisatsune J, Nakayama M, Isomoto H, Kurazono H, Mukaida N, Mukhopadhyay AK, Azuma T, Yamaoka Y, Sap J, Yamasaki E, Yahiro K, Moss J, Hirayama T: Molecular characterization of Helicobacter pylori VacA induction of IL-8 in U937 cells reveals a prominent role for p38MAPK in activating transcription factor-2, cAMP response element binding protein, and NF-kappaB activation. J Immunol 2008, 180:5017-5027.

6. Schluger NW, Rom WN: The host immune response to tuberculosis. Am J Respir Crit Care Med 1998, 157:679-691.

7. Addlagatta A, Quillin ML, Omotoso O, Liu JO, Matthews BW: Identification of an SH3-binding motif in a new class of methionine aminopeptidases from Mycobacterium tuberculosis suggests a mode of interaction with the ribosome. Biochemistry 2005, 44:7166-7174.
8. Vergne I, Chua J, Singh SB, Deretic V: Cell biology of mycobacterium tuberculosis phagosome. Annu Rev Cell Dev Biol 2004, 20:367-394.

9. Parish T, Stoker NG: Mycobacteria: bugs and bugbears. Methods Mol Biol 1998, 101:1-13.

10. Rogall T, Wolters J, Flohr T, Böttger EC: Towards a phylogeny and definition of species at the molecular level within the genus Mycobacterium. Int J Syst Bacteriol 1990, 40:323-330.

11. Narayanan SS, Ramanujan A, Krishna S, Nampoothiri KM: Purification and biochemical characterization of Methionine Aminopeptidase (MetAP) from Mycobacterium smegmatis mc2155. Appl Biochem Biotechnol 2008, 151:512-521.

12. Olaleye O, Raghunand TR, Bhat S, He J, Tyagi S, Lamichhane G, Gu P, Zhou J, Zhang Y, Grosset J, Bishai WR, Liu JO: Methionine aminopeptidases from Mycobacterium tuberculosis as novel antimycobacterial targets. Chem Biol 2010, 17:86-97.

13. McCarthy TR, Torrelles JB, MacFarlane AS, Katawczik M, Kutzbach B, Desjardin LE, Clegg S, Goldberg JB, Schlesinger LS: Overexpression of Mycobacterium tuberculosis manB, a phosphomannomutase that increases phosphatidylinositol mannoside biosynthesis in Mycobacterium smegmatis and mycobacterial association with human macrophages. Mol Microbiol 2005, 58:774-790.

14. Keiser TL, Azad AK, Guirado E, Bonacci R, Schlesinger LS: Comparative transcriptional study of the putative mannose donor biosynthesis genes in virulent mycobacterium tuberculosis and attenuated mycobacterium bovis BCG strains. Infect Immun 2011, 79:4668-4673.

15. Staels B, Dallongeville J, Auwerx J, Schoonjans K, Leitersdorf E, Fruchart JC: Mechanism of action of fibrates on lipid and lipoprotein metabolism. Circulation 1998, 98:2088-2093.

16. Kim M-J, Wainwright HC, Locketz M, Bekker L-G, Walther GB, Dittrich $C$, Visser A, Wang W, Hsu F-F, Wiehart U, Tsenova L, Kaplan G, Russell DG: Caseation of human tuberculosis granulomas correlates with elevated host lipid metabolism. EMBO Mol Med 2010, 2:258-274.

17. Mathivat A, Cottet J: Clinical trials on the hypocholesteremia-producing effect of 2-phenylbutyric acid. Bull Mem Soc Med Hop Paris 1953, 69:1030-1048.

18. Schäfer G, Guler R, Murray G, Brombacher F, Brown GD: The role of scavenger receptor $\mathrm{B} 1$ in infection with Mycobacterium tuberculosis in a murine model. PLOS One 2009, 4:e8448.

19. Peyron P, Bordier C, N'Diaye EN, Maridonneau-Parini I: Nonopsonic phagocytosis of Mycobacterium kansasii by human neutrophils depends on cholesterol and is mediated by CR3 associated with glycosylphosphatidylinositolanchored proteins. J Immunol 2000, 165:5186-5191.

20. Reich-Slotky R, Kabbash CA, Della-Latta P, Blanchard JS, Feinmark SJ, Freeman S, Kaplan G, Shuman HA, Silverstein SC: Gemfibrozil inhibits Legionella pneumophila and Mycobacterium tuberculosis enoyl coenzyme A reductases and blocks intracellular growth of these bacteria in macrophages. J Bacteriol 2009, 191:5262-5271.

21. Scatena R, Nocca G, Sole PD, Rumi C, Puggioni P, Remiddi F, Bottoni P, Ficarra S, Giardina B: Bezafibrate as differentiating factor of human myeloid leukemia cells. Cell Death Differ 1999, 6:781-787.

22. Berger JP, Akiyama TE, Meinke PT: PPARs: therapeutic targets for metabolic disease. Trends Pharmacol Sci 2005, 26:244-251.

23. Kliewer SA, Umesono K, Noonan DJ, Heyman RA, Evans RM: Convergence of 9-cis retinoic acid and peroxisome proliferator signalling pathways through heterodimer formation of their receptors. Nature 1992, 358:771-774.

24. Dreyer C, Krey G, Keller H, Givel F, Helftenbein G, Wahli W: Control of the peroxisomal beta-oxidation pathway by a novel family of nuclear hormone receptors. Cell 1992, 68:879-887.

25. Tugwood JD, Issemann I, Anderson RG, Bundell KR, McPheat WL, Green S: The mouse peroxisome proliferator activated receptor recognizes a response element in the $5^{\prime}$ flanking sequence of the rat acyl $\mathrm{CoA}$ oxidase gene. EMBO J 1992, 11:433-439.

26. Marx N, Duez H, Fruchart J-C, Staels B: Peroxisome proliferator-activated receptors and atherogenesis: regulators of gene expression in vascular cells. Circ Res 2004, 94:1168-1178.

27. Muñoz S, Rivas-Santiago B, Enciso JA: Mycobacterium tuberculosis entry into mast cells through cholesterol-rich membrane microdomains. Scand I Immunol 2009, 70:256-263.

28. O'Neill LAJ, Golenbock D, Bowie AG: The history of Toll-like receptors redefining innate immunity. Nat Rev Immunol 2013, 13:453-460. 
29. Means TK, WANG S, Lien E, Yoshimura A, Golenbock DT, Fenton MJ: Human toll-like receptors mediate cellular activation by Mycobacterium tuberculosis. J Immunol 1999, 163:3920-3927.

30. Ehlers S: Role of tumour necrosis factor (TNF) in host defence against tuberculosis: implications for immunotherapies targeting TNF. Ann Rheum Dis 2003, 62:37ii-42ii.

31. Hölscher C, Reiling N, Schaible UE, Hölscher A, Bathmann C, Korbel D, Lenz I, Sonntag T, Kröger S, Akira S, Mossmann H, Kirschning CJ, Wagner H, Freudenberg M, Ehlers S: Containment of aerogenic Mycobacterium tuberculosis infection in mice does not require MyD88 adaptor function for TLR2, -4 and -9. Eur J Immunol 2008, 38:680-694.

32. Takano H, Nagai T, Asakawa M, Toyozaki T, Oka T, Komuro I, Saito T, Masuda Y: Peroxisome proliferator-activated receptor activators inhibit lipopolysaccharide-induced tumor necrosis factor-alpha expression in neonatal rat cardiac myocytes. Circ Res 2000, 87:596-602.

33. Antonenkov VD, Croes K, Waelkens E, Van Veldhoven PP, Mannaerts GP: Identification, purification and characterization of an acetoacetyl-CoA thiolase from rat liver peroxisomes. Eur J Biochem 2000, 267:2981-2990

34. Thompson SL, Krisans SK: Rat liver peroxisomes catalyze the initial step in cholesterol synthesis: the condensation of acetyl-CoA units into acetoacetyl-CoA. JBC 1990, 265:5731-5735.

35. Huth W, Jonas R, Wunderlich I, Seubert W: On the mechanism of ketogenesis and its control: purification, kinetic mechanism and regulation of different forms of mitochondrial acetoacetyl-CoA thiolases from ox liver. Eur J Biochem 1975, 59:475-489.

36. Clinkenbeard KD, Reed WD, Mooney RA, Lane MD: Intracellular localization of the 3-hydroxy-3-methylglutaryl coenzme A cycle enzymes in liver: separate cytoplasmic and mitochondrial 3-hydroxy-3-methylglutaryl coenzyme A generating systems for cholesterogenesis and ketogenesis. JBC 1975, 250:3108-3116

37. Lalloyer F, Staels B: Fibrates, glitazones, and peroxisome proliferatoractivated receptors. Arterioscler Thromb Vasc Biol 2010, 30:894-899.

38. Bocher V, Chinetti G, Fruchart J-C, Staels B: Role of the peroxisome proliferator-activated receptors (PPARS) in the regulation of lipids and inflammation control. J Soc Biol 2002, 196:47-52.

39. Baures PW: Is RORY a therapeutic target for treating Mycobacterium tuberculosis infections? Tuberculosis (Edinb) 2012, 92:95-99.

40. Keane J, Gershon S, Wise RP, Mirabile-Levens E, Kasznica J, Schwieterman WD, Siegel JN, Braun MM: Tuberculosis associated with infliximab, a tumor necrosis factor alpha-neutralizing agent. N Engl J Med 2001, 345:1098-1104.

41. Núñez Martínez O, Ripoll Noiseux C, Carneros Martín JA, González Lara V, Gregorio Marañón HG: Reactivation tuberculosis in a patient with anti-TNF-alpha treatment. Am J Gastroenterol 2001, 96:1665-1666.

42. Flynn JL, Goldstein MM, Chan J, Triebold KJ, Pfeffer K, Lowenstein CJ, Schreiber R, Mak TW, Bloom BR: Tumor necrosis factor-alpha is required in the protective immune response against Mycobacterium tuberculosis in mice. Immunity 1995, 2:561-572.

43. Garbe TR: Co-induction of methyltransferase Rv0560c by naphthoquinones and fibric acids suggests attenuation of isoprenoid quinone action in Mycobacterium tuberculosis. Can J Microbiol 2004, 50:771-778

doi:10.1186/0717-6287-47-42

Cite this article as: Kim et al:: Normalization of the levels of inflammatory molecules in Mycobacterium smegmatis-infected U937 cells by fibrate pretreatment. Biological Research 2014 47:42.

\section{Submit your next manuscript to BioMed Central and take full advantage of:}

- Convenient online submission

- Thorough peer review

- No space constraints or color figure charges

- Immediate publication on acceptance

- Inclusion in PubMed, CAS, Scopus and Google Scholar

- Research which is freely available for redistribution

Submit your manuscript at www.biomedcentral.com/submit
C Biomed Central 